$\begin{array}{ll} & \text { Etnográfica } \\ \text { etnográfica } & \text { Revista do Centro em Rede de Investigação em }\end{array}$

Antropologia

vol. 15 (3) | 2011

Vol. 15 (3)

\title{
Suspeito empreendedor de si: trajeto e sofrimento de um adolescente durante intervenção socioeducativa
}

Self-entrepreneur under suspicion: path and suffering of a teenager during socio-educational intervention

\section{Paulo Artur Malvasi}

\section{(2) OpenEdition}

\section{Journals}

\section{Edição electrónica}

URL: https://journals.openedition.org/etnografica/1050

DOI: 10.4000/etnografica.1050

ISSN: 2182-2891

\section{Editora}

Centro em Rede de Investigação em Antropologia

\section{Edição impressa}

Data de publição: 1 outubro 2011

Paginação: 501-521

ISSN: 0873-6561

\section{Refêrencia eletrónica}

Paulo Artur Malvasi, «Suspeito empreendedor de si: trajeto e sofrimento de um adolescente durante intervenção socioeducativa», Etnográfica [Online], vol. 15 (3) | 2011, posto online no dia 23 outubro 2011, consultado o 10 fevereiro 2022. URL: http://journals.openedition.org/etnografica/1050 ; DOI: https://doi.org/10.4000/etnografica.1050

\section{(c) (†) 8}

Etnográfica is licensed under a Creative Commons Attribution-NonCommercial 4.0 International License. 


\title{
Suspeito empreendedor de si: trajeto e sofrimento de um adolescente durante intervenção socioeducativa
}

\section{Paulo Artur Malvasi}

\begin{abstract}
Este trabalho analisa a natureza social e política do sofrimento de um jovem em cumprimento de medida socioeducativa. Partindo de uma perspectiva foucaultiana do poder, o artigo considera a experiência subjetiva do jovem em sua interação com o sistema socioeducativo; observa as manifestações do poder na ação de uns sobre os outros, no agir reiterado em torno de saberes e poderes que delineiam os modos de ação sobre o campo de ação do jovem. A análise da experiência subjetiva de um adolescente durante o cumprimento de medida socioeducativa revela o modo pelo qual a intervenção pode situá-lo no limite das possibilidades de integração, intensificando as aflições de uma vida sob constante suspeição. A abordagem adotada permite observar de que modo o jovem elabora significados sobre o sistema socioeducativo e como expressa por meio de palavras, gestos e movimentos as contradições desta política pública. A posição do jovem como alguém que deve explorar individualmente os riscos, as perdas e as benesses das suas escolhas constitui uma zona de confluência entre o discurso socioeducativo e o do crime. Simultaneamente, um aparato governamental difuso e um modelo de gestão do comércio de drogas acompanham o jovem no trajeto de cumprimento de medida socioeducativa, cada qual dos sistemas com suas próprias estratégias e esquemas de gestão da sua vida.
\end{abstract}

PALAVRAS-CHAVE: sofrimento social, poder e violência, medida socioeducativa.

\section{A MÁXIMA DE QUE A ETNOGRAFIA SE CARACTERIZA COMO A ABORDAGEM das experiências humanas que se constroem a partir de uma experiência pessoal constitui possivelmente, para os "não iniciados", um dos pontos mais intrigan- tes da pesquisa antropológica. Em minha atuação profissional junto aos agen- tes do "sistema socioeducativo", a relação direta e pessoal que estabeleço com jovens que trabalham no tráfico de drogas, "em conflito com a lei”, é motivo}


de curiosidade, levanta dúvidas e provoca surpresa. "A vida é loka e nela estou de passagem", dizem meus interlocutores. Esta frase sintetiza bem o sentido de imprevisibilidade da "caminhada" de um traficante. ${ }^{1}$ Em um campo tão distinto do domínio do crime - o da antropologia -, o adágio "o caminho se faz ao andar" se reafirma: lidar com o imponderável é uma condição do ofício do antropólogo. Após dois anos de pesquisa de campo, minha "caminhada" segue pelos labirintos da experiência de jovens que vivem no fio da navalha, nas interfaces do conflito social mais recorrente nas cidades brasileiras: o do combate das forças governamentais ao pequeno tráfico feito em esquinas, nas ruas de determinados bairros.

A especificidade de meu trabalho como pesquisador dá-se no trânsito entre as margens e o centro do sistema socioeducativo. ${ }^{2} \mathrm{Na}$ pesquisa de campo, mergulho no cotidiano de jovens que trabalham no comércio varejista de drogas, frequento o território em que residem, conheço suas famílias e seus amigos, acompanho os fluxos de significados, as práticas e as performances em sua vida cotidiana. Minha inserção no campo é complexa, pois, além de realizar pesquisas no terreno dos próprios jovens, sou professor do Programa de Mestrado "Adolescentes em Conflito com a Lei", cujos alunos são profissionais de diversas áreas relacionadas ao trabalho com tal grupo: psicólogos, defensores públicos, promotores, policiais, assistentes sociais, educadores e afins. Meus alunos - que muitas vezes experimentam as mesmas contradições que eu - ocupam posições institucionais em órgãos do Estado e em organizações de defesa de direitos e de execução de políticas sociais. Esta pesquisa se realiza, portanto, em terreno ambíguo, em que a violência institucional que combato é reproduzida por um

l A "caminhada" pode ser considerada como a trajetória de um ladrão no "crime". Pode ainda expressar uma série de procedimentos a serem cumpridos pelo criminoso (Biondi 2010). A expressão, entretanto, não se limita às fronteiras internas do "crime": a "caminhada" se refere a trajetos de vida, que envolvem relações comunitárias e sociais, de muitos jovens que se utilizam dessa expressão.

2 Utilizo os termos "margens" e "centro" para caracterizar a situação institucional do sistema socioeducativo. No Estatuto da Criança e do Adolescente (ECA - Lei n. ${ }^{\circ}$ 8069/90, Brasil), o ato infracional praticado por adolescentes deve receber a aplicação de medidas socioeducativas, pois os menores de dezoito anos são "penalmente inimputáveis" (ECA, art. $\left.^{\circ} 104 .^{\circ}\right)$. As medidas socioeducativas são operadas por um sistema que inicia com a abordagem das polícias, envolve o poder judiciário que aplica as medidas, organizações estatais especializadas na medida de privação de liberdade, e poderes públicos e instituições civis responsáveis pela execução das medidas em meio aberto. O sistema socioeducativo constitui um campo político complexo que envolve diversos atores institucionais, interfaces entre os programas de atendimento, o poder judiciário, Ministério Público e conselhos de direitos, polícias e secretarias municipais e estaduais (principalmente das áreas de saúde e assistência social), parcerias entre órgãos governamentais e não governamentais. Envolve também a busca por "ações descentralizadas", construídas de modo "participativo", a "articulação intersetorial das áreas de políticas públicas" no âmbito municipal, estadual e federal, para garantir a "universalidade" das políticas e serviços. Uma imbricada rede de interesses, perspectivas e disputas marca o sistema socioeducativo. No cerne de todo este emaranhado institucional, há (idealmente) o adolescente autor de ato infracional, o "sujeito de direitos" para o qual todo o sistema deve convergir. 
campo institucional em que, de certa forma, eu atuo. Lembro por isto aos meus alunos que a antropologia não serve para "pacificar", mas para "manter o mundo em desequilíbrio, puxando tapetes, virando mesas e soltando rojões". O ofício do antropólogo é como o de um “mercador do espanto” (Geertz 2001: 65).

Considerar os jovens com os quais trabalho como margem do sistema socioeducativo é uma escolha que marca uma referência simbólica e uma abordagem teórica e política do sistema socioeducativo. Sigo a perspectiva de Das e Poole (2008), ao tomar as margens como elos que constituem as condições necessárias para se pensar etnograficamente o Estado como objeto teórico e político. Ao tomar uma política pública, como o sistema socioeducativo, desde suas margens, não retrato apenas dinâmicas territoriais específicas nem segmentos populacionais considerados excluídos ou marginalizados. Procuro antes mapear sítios de práticas em que (certas) leis e outros mecanismos de poder e alteridade são acionados (Das e Poole 2008). No caso pesquisado, refiro-me às intervenções governamentais junto a pessoas consideradas insuficientemente socializadas segundo o marco normativo do Estado - os adolescentes -, e, ainda, "em conflito com a lei".

Este artigo é baseado em uma etnografia realizada em dois bairros do Estado de São Paulo, Brasil, onde existe a coincidência entre o comércio varejista de drogas feito nas ruas, relações de vizinhança e ação intensiva de forças de repressão/assistência/atenção governamentais. A etnografia aborda, especificamente, as interfaces entre os jovens que trabalham no tráfico de drogas e um poder constituído para intervir no início da "carreira criminosa" - o sistema socioeducativo. No presente texto, analiso as ambiguidades na experiência de um adolescente ao passar pelo sistema socioeducativo; considero como, no cotidiano deste adolescente, são incorporados mecanismos de gestão da sua vida e quais as formas de lide com tal engenharia "socioeducativa".

Parto de uma inspiração foucaultiana da análise do poder, isto é, considero entre o adolescente e o sistema socioeducativo um poder disperso e cotidiano, que "está em toda parte" e "provém de todos os lugares" (Foucault 2001: 89). ${ }^{3}$ Procuro, portanto, observar as manifestações do poder na ação de uns sobre os outros, no agir reiterado em torno de saberes e poderes que delineiam os modos

3 Na primeira aula do curso "Segurança, Território e População", Foucault sustenta que a sua análise do poder são indicações de opção, “nem princípios, nem regras, nem teoremas” (2008b: 3). Não é proposta uma teoria geral do poder, mas que o poder seja tomado como "um conjunto de mecanismos e de procedimentos que têm como papel ou função e tema - mesmo que não o consigam - justamente o poder" (2008b: 4). Segundo Foucault, tais mecanismos são parte intrínseca de diversas relações (familiares, sexuais, de produção, etc.), sendo efeito e causa delas e, portanto, é possível percorrer de uma maneira "ao mesmo tempo lógica, coerente e válida o conjunto de mecanismos de poder e apreendê-los no que podem ter de específico num momento dado, durante um período dado, num campo dado” (2008b: 5). A análise dos mecanismos de poder para Foucault tem "o papel de mostrar quais são os efeitos de saber que são produzidos em nossas sociedades pelas lutas, os choques, os combates que nela se desenrolam, e pelas táticas de poder que são os elementos dessa luta" (2008b: 5). 
de ação sobre o campo de ação de um jovem que recebeu medidas socioeducativas; sua experiência, suas relações e suas interações com os "outros" - os técnicos do sistema, a mãe, os amigos, os companheiros de trabalho no tráfico, o próprio pesquisador. Isto implica reconhecer, no contexto estudado, formas de conhecimento, regimes de autoridade e práticas de intervenção de diferentes origens sobre a vida do jovem "traficante".

A escolha de uma trajetória em particular se deve à proximidade que tenho com o adolescente, sua família e rede comunitária. Tal proximidade permite descer ao cotidiano. Ao acompanhar uma trajetória de cumprimento de medidas socioeducativas, a etnografia recupera a voz desta personagem e descreve de que modo os sentimentos com relação à sua passagem pelo sistema socioeducativo são incorporados em sua vida cotidiana (Das 2006). Parto do pressuposto de que as emoções são experiências e estratégias retóricas pelas quais as pessoas expressam, reclamam, promovem, proíbem ou justificam suas ações (Epele 2010). Esta abordagem permite a investigação das experiências individuais de sofrimento em um contexto delimitado, observando as ambiguidades das práticas institucionais voltadas para abrandar o sofrimento dos sujeitos tidos como excluídos e vulneráveis e que, paradoxalmente, resultam em sua intensificação (Kleinman, Das e Lock 1997).

A análise da experiência subjetiva de um adolescente durante seis meses de cumprimento de duas diferentes "medidas socioeducativas" revela o modo pelo qual a intervenção socioeducativa, seguindo o objetivo institucional de "reinserir" o jovem, pode situá-lo no limite das possibilidades de integração, intensificando as aflições de uma vida sob constante suspeição. A abordagem aqui adotada permite observar de que modo o jovem elabora significados sobre o sistema socioeducativo e como expressa por meio de palavras, gestos e movimentos suas contradições.

\section{FRIEZA DO CÁLCULO E SOFRIMENTO: A VIDA LOKA DE ZEZINHO}

Contarei, a partir de agora, a trajetória de Zezinho durante seis meses, um "quase-personagem" que sustenta as ideias que desenvolvo neste ensaio. Trago à tona uma trajetória empírica, com o intuito de materializar o sofrimento presente na experiência dos adolescentes em cumprimento de medidas socioeducativas os quais tenho acompanhado. ${ }^{4}$

Conheço Zezinho desde que ele tinha 11 anos de idade; em 2009, quando acompanhei sua trajetória de medidas socioeducativas, ele contava 16 anos.

4 Este caso foi apresentado em outro artigo (Malvasi 2011). O nome dado ao adolescente é fictício, assim como os nomes de seus familiares, citados no transcorrer do artigo: as informações sobre a trajetória de Zezinho que não observei presencialmente são oriundas de suas narrativas. Os trechos que se referem a acontecimentos que presenciei são aqueles nos quais menciono minha presença. 
Trabalhei com sua mãe, Dona Ivone, em um programa de geração de renda, do qual eu era "facilitador", numa cidade localizada nas franjas da região metropolitana de São Paulo. Zezinho é filho adotivo de Dona Ivone (63) e de Seu Patrício (61). Conversei com Dona Ivone em 2009, após três anos sem nos vermos. Ela me contou, então, que o filho havia "virado traficante". Sua expressão facial demonstrava vergonha. Chegou a cometer um "ato falho", negando ser sua mãe. Quando perguntei a ela se Zezinho era seu neto - era o que eu pensava -, ela respondeu: "Meus filhos... são todos honestos".

Zezinho mora em um dos dois bairros em que realizei pesquisa de campo sobre a atividade do tráfico de drogas. Ele foi um dos meus principais interlocutores. Sua casa é de alvenaria, tem aproximadamente $40 \mathrm{~m}^{2}$ e é situada em um terreno de $150 \mathrm{~m}^{2}$ onde há mais duas casas, de tamanho semelhante, em que moram filhos e netos de Dona Ivone e de Seu Patrício. Famílias extensas, com laços variados além da consanguinidade, e uma rede de ajuda e proteção mútua que difere muito do modelo pretensamente "estruturado" da família nuclear de classe média no Brasil (Fonseca 2005). Exatamente na frente da casa de Zezinho, existe um ponto de venda de drogas: uma "lojinha". O ponto é estratégico, pois ao lado da casa há um beco e, no final deste, um rio e um matagal para onde fugir da polícia.

Entre fevereiro e julho de 2009, Zezinho ganhou dinheiro, foi preso, recebeu "medida de internação", saiu e esteve em cumprimento da "medida de liberdade assistida".

No dia 20 de fevereiro, véspera de Carnaval, Zezinho estava vendendo cocaína e crack em frente à sua casa. Eram mais ou menos 23 horas e ele já contabilizava cinco mil reais em vendas e mil e duzentos de lucro para si. Da frente de casa, com seu pai a aproximadamente 30 metros, ele viu a polícia chegando: "Eu fiquei olhando, olhando, para ver se era a força [a polícia]... Aí quando eu vi, era mesmo e já estava perto. Aí eu joguei do lado a mercadoria e fui para perto do meu pai, que estava na porta do bar". A polícia o abordou, perguntou de quem era a droga e o dinheiro, puxou seu braço, deu uma bronca em seu pai, que não entendia o que estava acontecendo. O pai o acompanhou até a delegacia. Durante o trajeto, uma série de xingamentos e provocações foi proferida contra ele pelos policiais. Zezinho foi encaminhado para a Fundação de Atendimento Socioeducativo (Fundação Casa), órgão do Estado de São Paulo responsável pela internação de adolescentes.

Tive a oportunidade de reencontrar Zezinho na Fundação Casa durante a internação. Fui convidado, como diretor de uma ONG, para a cerimônia de formatura dos internos. O espaço é uma prisão: três complexos de grades, portas e seguranças até que se chegue ao local onde os adolescentes permanecem. Quando cheguei à última grade, observei os formandos descendo para o evento: divididos em grupos de cinco, roupas iguais, cabelos raspados, cabeças baixas e mãos para trás; a cada segurança por que passavam diziam: 
"dá licença, senhor", “dá licença, senhora”. Entrei pelo corredor, recebendo indicação da sala para onde deveria me encaminhar. Os adolescentes estavam em uma sala com seguranças, de um lado, e nós fomos para outra, onde seria o evento. Os educadores, psicólogos e outros técnicos ficaram com os convidados. Quando estávamos acomodados, trouxeram os jovens para a sala; quarenta e cinco ao todo. Antes da distribuição dos certificados do Curso de Empreendedorismo e Turismo, discursaram o representante do Fórum, a diretora da unidade, o psicólogo responsável, o presidente do Conselho dos Direitos da Infância e Adolescência e eu mesmo, como representante da "sociedade civil”. Dois educadores cantaram, acompanhados por violão, enquanto os adolescentes eram chamados para receberem seus certificados. Eu estava ao lado da diretora da unidade de internação e comentei com ela como os meninos tinham uma aparência boa, saudável, destaquei o quanto eram bonitos. Ela disse: "Também... aqui, eles têm dentista, médico, comida boa, aqui dormem bem, não usam drogas, ficam menos vulneráveis".

Para encerrar o evento, alguns adolescentes apresentaram uma "dramatização". O esquete, singelo a despeito da desenvoltura de alguns internos, consistia no seguinte: um jovem sai com o diploma da Fundação Casa (curso de turismo, empreendedorismo, etc.) para procurar emprego. Ao chegar aos estabelecimentos, o jovem se apresenta e mostra o diploma. Os entrevistadores demonstram apreensão; afastam-se, mudam de assunto, evidenciando preconceito pelo fato de o jovem ter passado pela internação. A visão dos jovens, apresentada na dramatização, é a do estigma de quem passou por uma situação que caracteriza a pessoa como "criminosa". Zezinho representava um dos garotos que está procurando emprego. Em sua performance, entrega seu currículo em três lugares diferentes. Sem conseguir uma oportunidade, volta, ao final do dia, para seu bairro e encontra um grupo de amigos que estão trabalhando no "movimento" (tráfico de drogas). Seus amigos o convidam para voltar a trabalhar no tráfico e ele diz que não, não quer; está procurando emprego. Seus amigos estão fumando maconha e circulam o cigarro até a mão de Zezinho. No momento em que ele segura o cigarro, a polícia chega. Os adolescentes da Casa riram bastante após a apresentação, comungando significados. A mensagem que transmitiram foi patente: independentemente do que façam, ou deixem de fazer, serão, sempre, considerados suspeitos; ao saírem da internação, sua marca será a de ex-internos da "FEBEM".

Zezinho ficou aproximadamente dois meses internado. O prazo de internação não é predeterminado; depende da decisão do juiz, que costuma seguir a

5 Atualmente a instituição responsável pela privação de liberdade de adolescentes no Estado de São Paulo é a Fundação Casa, antiga FEBEM. Apesar de o nome ter mudado em 2006, grande parte da população chama a Fundação Casa pelo antigo nome - FEBEM -, que é identificado, popularmente, como sinônimo de prisão de adolescentes "bandidos" e "perigosos". 
indicação apresentada no laudo dos técnicos da Fundação Casa. Geralmente, os laudos são assinados por psicólogos. Não tive acesso ao laudo, mas Dona Ivone me mostrou uma carta de Zezinho que sensibilizou a psicóloga ao ponto de esta escrever um relatório recomendando a soltura de seu filho. Na carta, endereçada à mãe, Zezinho aponta uma mudança comportamental: "Aqui descobri que o crime não compensa; to no sofrimento, mãe. Me perdoa, mãe; to aprendendo uma profissão, pra lá fora enfrentar o mundão. Vou-me armar com enxadas e pá; minha mão calejar. Cuidar bem da minha família, uma família firmona, mãe. Só tenha uma certeza: de que um dia seu filho vai voltar".

No início de abril Zezinho foi solto e iniciou o cumprimento da medida de liberdade assistida. Encontrei-o na segunda semana de atividades da liberdade assistida, quando foi para uma oficina de rap. Ao final da atividade, levei-o para casa e ficamos por mais ou menos uma hora conversando. Perguntei a ele o que é a liberdade assistida. Respondeu:

“- É um documento que eu assino, para o juiz ver que eu estou indo lá, estou comparecendo, estou fazendo o que ele pede... Tem Conselho, tem carro à paisana e tem polícia... tudo de olho em mim; na guarda do juiz. Aí na escola... eu ando na rua, assim ele sabe tudo. Ele sabe aonde eu vou, o que eu faço, da escola... Eles vão lá; perguntam como eu estou.

- Eles quem? - perguntei.

- Os policiais".

E continuou a descrição da relação que imagina ter (ou que de fato tem) com as instituições do sistema socioeducativo:

"Só que eu não sei disso, né? A psicóloga é que me avisou. Ela falou; 'O juiz ta na sua cola; ele ta com olho deste tamanho em você [e fez o sinal com a mão abrindo os olhos]; pensa que não tem ninguém de olho em você? Mas a polícia, a diretora da escola, ta todo mundo de olho em você".

Perguntei o que ele pensava sobre isso:

"Não vou falar que eu acho bom, porque fui eu que cometi este erro e tenho que pagar. Deixei vergonha na família, joguei o nome da minha família na lama".

Ao deixá-lo em casa, conversei com Dona Ivone e pedi permissão para visitá-los uma vez por semana. Ela demonstrou satisfação. Temos uma relação de amizade; convivemos com certa intimidade durante três anos. Zezinho também pareceu gostar, talvez tenha sido apenas simpático. Voltei durante três semanas consecutivas, por volta das 11 horas da manhã, e Zezinho estava 
sempre dormindo. Em um dos dias, sua mãe me disse que estava desconfiada de que Zezinho havia voltado para o "crime". Disse que "é uma judiação" o que acontece com os jovens de hoje em dia; que muitos "meninos do tráfico" cresceram em sua casa, eles eram "bons". Insistiu para que eu voltasse para conversar com Zezinho.

Voltei no dia combinado, 10 de junho. Zezinho estava no bar conversando com alguns homens mais velhos, um travesti e um amigo, este sentado em uma bicicleta. "É o gerente da biqueira", disse-me a tia de Zezinho. ${ }^{6}$ Dona Ivone saiu ao portão no momento que cheguei e começou a gritar com Zezinho e seu colega da bicicleta. "Olha menino", dizia se dirigindo ao rapaz de bicicleta, "eu não quero mais você aqui na porta da minha casa; que história é essa que você plantou maconha no meu jardim?" Começaram a bater boca. Zezinho manteve distância, como se fosse absolutamente indiferente ao ocorrido. Dona Ivone chamou Zezinho: "Você acha que vai ser alguma coisa sendo traficante? Você não vai ser nada. Meus filhos são todos trabalhadores, agora você, que eu adotei e cuidei como se fosse meu filho, faz isso". Zezinho continuava a expressar indiferença. "Você sempre foi frio e calculista", disse Dona Ivone. Zezinho riu, talvez porque veja estas características como qualidades. Dona Ivone, até então com uma expressão severa, riu, resignada.

No dia 24 de junho, voltamos a nos encontrar. Convidei Zezinho pra ir até o centro; era aniversário da cidade. Tradicionalmente, acontece um desfile cívico de que todas as escolas e ONG da cidade participam. Conversei com Dona Ivone enquanto aguardava o garoto, e ela falou sobre seus problemas de saúde, dando a entender que as preocupações com Zezinho deixavam-na desgostosa. Dona Ivone mudou de perspectiva repentinamente, revelando uma percepção muito pessoal sobre seu filho e os amigos dele. Lembrou dos vários meninos que hoje estão no tráfico e "cresceram" em sua casa. Ela atribui ao ganho "fácil" - e tudo o que o acompanha, como boas roupas, utensílios tecnológicos, lazer, mulheres - a grande motivação para os jovens aderirem ao tráfico. "Essa geração de hoje é muito difícil. Eles têm outra cabeça".

Zezinho saiu de casa pronto para ir comigo ao centro da cidade. Vestindo um casaco vermelho de gola alta fechada por uma corrente dourada, tênis Nike brilhando de tão novos, bermuda larga vermelha e um boné azul e vermelho, estava animado com o passeio. Chegamos ao centro e ele caminhava com um estilo facilmente reconhecido pelos seus pares geracionais. Passos largos, cabeça erguida, gestos largos com as mãos para cumprimentar as pessoas. Percebi olhares de admiração e outros de atenção de muitos jovens que

6 "Biqueira" é o nome dado pelos meus interlocutores aos pontos de venda de drogas. Esses são chamados também de "boca" ou "lojinha" - ou ainda de "shopinho" - dependendo do contexto e do local. "Lojinha" e "shopinho" são denominações mais recentes. "Biqueira" é termo que tem sido mais usado nas conversas entre os comerciantes e "boca" o que representa os aspectos mais violentos do "mundo do crime". 
o conheciam; e não eram poucos. Paramos, então, em uma lanchonete, onde havia um grupo de amigos dele. Sentou-se e ficou conversando. Fiquei alguns minutos com o grupo, composto por alguns jovens de estilo parecido, outros não. Despedi-me do grupo, pois tinha que acompanhar o desfile da ONG à qual pertenço. Quando voltei, os garotos estavam desolados na praça em frente à lanchonete. Eles haviam sofrido uma "batida" policial na frente de centenas de pessoas que acompanhavam a festa. O dono desconfiara de que eles pudessem estar observando o local para tramar um assalto - pelo menos foi isto o que o policial argumentou, segundo a versão dos jovens. Zezinho, que estava imponente, vaidoso, agora mostrava expressão de revolta e humilhação. Ao deixá-lo em casa, no momento exato em que chegamos, a polícia passava lentamente em frente à sua casa. Os policiais olharam com agressividade para nós, como se fôssemos suspeitos.

Na última visita à casa de Zezinho, em 29 de julho, aconteceu algo inesperado. Ele estava no bar em frente à sua casa. Ficou meio sem jeito. Percebi que ele estava vendendo drogas. Chegou então um rapaz de, aparentemente, vinte e poucos anos, cabelo com reflexos loiros, correntes de prata, dirigindo um Vectra azul metálico com equipamento de som de última geração, e chamou Zezinho para ir com ele comprar vinho em uma adega tradicional da cidade. Zezinho me perguntou se eu sabia onde era a tal adega. Eu sabia. Então, o rapaz me chamou para ir com eles. Entramos no automóvel e saímos em direção ao local. Carro impecável, com equipamento de som tocando Racionais MC's, o grupo de rap mais conhecido do Brasil. A caminho, descobri que o rapaz não tinha carteira de habilitação. Fiquei um pouco apreensivo, mas percebi que estava em uma situação interessante para a pesquisa e tinha que seguir adiante.

Avisei o condutor do automóvel que é costume haver "comandos" (blitzes com parada e inspeção de carros e de condutores) na entrada da cidade. Paramos de esquina em esquina, observando de longe se havia algum "comando". Conseguimos entrar na autoestrada que contorna a cidade, antes de passarmos pela polícia. Seguimos até a última entrada e nos dirigimos à adega. Os rapazes compraram o vinho e conversaram um pouco com o "senhor" sobre os processos de produção da bebida.

Creio que pelo gosto do risco e da aventura, o rapaz que dirigia o automóvel resolveu voltar pelo centro da cidade, mesmo estando em um veículo rebaixado, com som bem alto, tocando música rap, sem usar o cinto de segurança, além da falta da carteira de habilitação (o que - exceto ouvir rap - no Brasil são infrações às leis de trânsito). Enquanto passávamos pelas ruas centrais, o rapaz comentou que não via o centro há uns dois anos e que saíra da cadeia há cinco semanas. Os dois observavam todas as ruas, as pessoas, os prédios do centro. Passamos, inclusive, em frente a policiais. Com o vinho aberto rodando de mão em mão, bebido a goles amplos e contundentes, os dois cantavam com fúria uma canção dos Racionais MC’s, encenando com gestos, poses e expressões faciais. 
“Deixa eu falá, pocê, tudo, tudo, tudo vai, tudo é fase irmão. Logo mais vamos arrebentar no mundão, de cordão de elite, 18 quilate, põe no pulso, logo bright, que tal, ta bom, de lupa bausch\&lomb, bombeta branca e vinho, champanhe para o ar, que é pra abrir nossos caminhos, pobre é o diabo, eu odeio ostentação, pode rir, ri, mas não desacredita não, é só questão de tempo, o fim do sofrimento, um brinde pros guerreiro, zé-povinho eu lamento, vermes que só faz peso na Terra, tira o zoio, tira o zoio, vê se me erra [...] Quente é mil grau, o que o guerreiro diz, o promotor é só um homem, Deus é o juiz, enquanto zé-povinho apedrejava a cruz, um canalha fardado, cuspiu em Jesus, Hó... aos 45 do segundo arrependido, salvo e perdoado, é Dimas o bandido, é louco o bagulho, arrepia na hora, Dimas primeiro vida loka da história, eu digo, glória... Sei que Deus ta aqui, e só quem é, só quem é vai sentir, e meus guerreiro de fé, quero ouvir... E meus guerreiro de fé, quero ouvir... irmão... Programado pra morrê nois é, certo [...] miséria traz tristeza, e vice-versa, inconscientemente, vem na minha mente inteira uma loja de tênis, o olhar do parceiro feliz de poder comprar, o azul, o vermelho, o balcão, o espelho, o estoque, a modelo, não importa, dinheiro é puta, e abre as portas, dos castelos de areia que quiser, preto e dinheiro são palavras rivais, é, então mostra pra esses cu como é que faz, o seu enterro foi dramático como um blues antigo, mas de estilo me perdoe de bandido, tempo pá pensar, quer parar, que se quer, viver pouco como um rei, ou muito como um Zé" (Vida Loka, parte 2, Racionais MC's). ${ }^{7}$

A ideia de vida loka (vida louca), expressa neste rap, é comumente utilizada em periferias paulistas, publicada em adesivos, em carros, pichações em muros, síntese do imponderável na casualidade. Ela parece revelar a imponderabilidade da experiência comum; o aparente caos que cada indivíduo deve gerenciar, mas, também, o reconhecimento de que o mistério do fluxo da vida cotidiana não é controlado por ações governamentais (como aquelas presentes no sistema socioeducativo) ou por qualquer poder humano. A complexidade da vida loka no interior do "crime" leva o jovem a um dilema: sair dele e procurar viver como um "Zé”, realizando trabalhos enfadonhos e mal remunerados, comuns aos moradores das periferias paulistas, sem acesso ao mundo de bens desejados, ou continuar vivendo como um "Rei", ainda que de maneira fugaz e perigosa. No limite, trata-se de uma escolha econômica.

7 Canção do álbum Nada como Um Dia após o Outro Dia, dos Racionais MC's, editado por Cosa Nostra, em 2002. Diversas expressões presentes na letra da música são comuns no vocabulário de jovens moradores das periferias paulistas. Não me proponho aqui a fazer uma interpretação desta letra, mas considero importante destacar a alusão ao personagem "Dimas", presente no evangelho bíblico: Dimas era um bandido que foi crucificado ao lado de Jesus Cristo e foi "perdoado" por este, que ao "salvar" a sua alma garantiu-lhe a vida eterna. 
Descrevi situações cotidianas, em certo sentido, imponderáveis, que delimitaram os contornos de uma forma de vida humana. No momento em que Zezinho me disse que iria continuar traficando, ele se autojustificou. Disse que sua mãe nunca teve nada e que ele nunca teria uma oportunidade. A transgressão foi explicada por um discurso que enfatiza a injustiça social no Brasil contemporâneo. Uma leitura precipitada pode indicar uma consciência racional e política nos moldes de movimentos políticos que se opõem à violência do Estado. Entretanto, a obstinação contra o "sistema" manifesta nas falas e nas performances estilo "bandido" de Zezinho revelam formas de resposta ao discurso dominante no sistema socioeducativo, contexto em que é difícil para ele responder às demandas de ajustamento exigidas. Esta impossibilidade é experimentada no cotidiano; como lidar com uma vida loka?

O trânsito pela rua, também por mim vivenciado, é exemplo de onde tudo é mesmo imponderável: a falta dos documentos de habilitação e do carro, ou o vinho sendo tomado enquanto se dirige não significam que seríamos apanhados pela polícia. Poderíamos sê-lo em qualquer outra situação, como aquela expressa no esquete durante a internação de Zezinho. O sentido transcendente reivindicado na música dos Racionais MC's, o "promotor é só um homem, Deus é o Juiz", revela o inusitado: a participação no mundo do consumo e a realização pelo dinheiro através da participação no tráfico de drogas é um crime, que merece punição, para os homens. E para Deus? Se existe a possibilidade de não serem julgados por Deus pelos crimes mundanos, estes jovens fogem, simbolicamente, da lógica moral da repressão ao crime; o chamamento ao divino enfatiza a ideia de um indivíduo "de passagem pela vida", que marca a disputa simbólica presente na expansão do marco discursivo do "crime".

Não tive mais convívio com Zezinho. Em uma das poucas vezes em que nos encontramos nas ruas do bairro, presenciei novamente seu dilema; ele estava com outro jovem, gerente (coordenador de vendas) de uma "biqueira", e a conversa versava sobre a fuga de Zezinho do posto de trabalho: ele "tomou um enquadro da polícia" e fugiu da "lojinha", passando uma semana sem "trabalhar" e, no momento em que os encontrei, eles conversavam sobre este fato: o gerente dizia que Zezinho não servia para o crime, pois se no "primeiro enquadro que você toma da polícia já some... Ladrão não fica entre a cruz e a espada; ladrão é ladrão". 8

8 "Tomou enquadro da polícia": expressão que significa que o jovem foi abordado pela polícia. Quanto ao termo "ladrão", para este grupo, refere-se, genericamente, àquele que é reconhecido como envolvido com o "crime", independentemente da modalidade de infração. O termo "bandido" costuma ter a mesma acepção. 


\section{DA INTERVENÇÃO SOCIOEDUCATIVA A SUSPEITO EMPREENDEDOR DE SI}

No centro da trama até agora descrita, sobressaem encontros humanos singulares entre pessoas (adolescente, seus pares, educadores e psicólogos, familiares, o próprio pesquisador) que desnudaram no cotidiano a própria configuração de poder que encerra a experiência de todos os envolvidos. Como ensina Veena Das (2006), a pesquisa antropológica não identifica um padrão de escala independente da perspectiva. Para o antropólogo, a questão é estabelecer um horizonte em que ele possa localizar os interlocutores em suas relações e interações com o outro. É uma perspectivação. A perspectiva adotada neste artigo está na posição ocupada pelo pesquisador como profissional do campo socioeducativo e em sua interação com um adolescente em cumprimento de medida socioeducativa. Interpreto nas próximas páginas a experiência de um adolescente em seu fluxo pelo sistema socioeducativo: o trajeto de Zezinho aos olhos do pesquisador revela um sistema de fragmentos, lacunas e violências.

A entrada de Zezinho para o sistema socioeducativo (definido no discurso institucional como um campo de "proteção" e "garantia de direitos") deu-se através da "guerra às drogas": ações de repressão institucional que levam jovens moradores de bairros de baixa renda, como o de Zezinho, a serem constantemente tidos como suspeitos. Ao ingressar no sistema socioeducativo, o rapaz experimentou uma série de situações de constrangimento. A aplicação de medida socioeducativa (primeiro a de internação e depois a de liberdade assistida) causou uma inflexão na vida do adolescente; a intervenção institucional delineou um complexo campo de poder sobre a vida de Zezinho, e suas diversas (re)ações desenharam a incorporação deste poder em sua vida cotidiana.

A medida de internação, como a prisão dos adultos (maiores de 18 anos de idade), é executada em locais que se situam nas margens, nos limiares da vida social. Além disto, a gestão da medida de internação de Zezinho foi marcada por dispositivos de controle cada vez mais apertados e intrusivos no que se refere a jovens assistidos, os "adolescentes em conflito com a lei". O isolamento do adolescente é combinado com um processo de mapeamento de sua vida familiar e comunitária que será conjugada, no momento do retorno ao lar, com a "guerra às drogas" das forças de segurança sobre jovens considerados suspeitos em sua vizinhança. Concretiza-se assim um modelo disciplinar na internação com uma intervenção sobre o ambiente do mercado de drogas no bairro de Zezinho. ${ }^{9}$

9 Ao analisar as leituras dos neoliberais americanos da política penal, Foucault interpretou as consequências do modelo de inteligibilidade deste pensamento. "É sobre o ambiente de mercado em que o indivíduo faz o seu crime e encontra uma demanda positiva ou negativa, é sobre isso que se deve agir. O que levantará o problema [...] da técnica dessa nova tecnologia ligada, creio eu, ao neoliberalismo, que é a tecnologia ambiental ou a psicologia ambiental nos Estados Unidos" (Foucault 2008a: 354). Foucault não aprofundou a análise dessa tecnologia nas aulas e textos posteriores às aulas no College de France em 1979. 
As expressões de Zezinho durante a internação - olhar perdido de desamparo e, ao mesmo tempo, reflexivo e resignado - inscrevem em seu corpo a presença do delito como demonstração da sujeição a que deve se submeter para se mostrar como alguém que quer mudar de vida. A possibilidade de ter uma recaída é a marca de seu lugar social no mundo institucional - suspeito, irá reincidir ou não? Em sua relação com os representantes do sistema socioeducativo, Zezinho representou o comportamento esperado para ser solto. Privado de liberdade, o adolescente percebe que é por meio do "bom comportamento", de seu "ajuste", que se dá a possibilidade de absolvição: as expressões faciais e a gestualidade do corpo, nos momentos em que pude presenciar sua relação com os representantes institucionais, foram marcadas por elementos de uma performance de submissão - mãos para trás, cabeça baixa, expressões de resignação que diferem substancialmente de sua linguagem, de seus gestos e movimentos na rua, entre seus pares. Zezinho expressa, sem o dizer, que não se submete. Ele lida com a lógica operada no sistema socioeducativo para se manter livre, manejando seu comportamento e narrativas de acordo com o esperado.

$\mathrm{Na}$ rua, Zezinho manteve a performance que o identifica como alguém de estilo "bandido" - como se canta no rap dos Racionais MC's. Ou seja, nos momentos em que se apresenta para o seu grupo de relações, nas "baladas" (diversões, geralmente em bares e danceterias) noturnas, em contextos nos quais pode seduzir e usar seu dinheiro, ele tem posturas corporais, gestos e movimentos de força, altivez, coragem. Ele sabe que, assim, recebe a atenção de garotas e o respeito de garotos. Desempenha com desenvoltura o estilo "bandido" e parece sentir-se adequado nele. Tal estilo não é estranho aos seus amigos, sejam do "mundo do crime", ou não. ${ }^{10}$ A mudança comportamental durante a internação não representa, contudo, necessariamente, manipulação ou falsificação de suas intenções. Sua fala sobre a "vergonha que deixou na família" indica a interiorização da culpa e a dúvida com relação a suas escolhas. A humilhação vivida por seu pai quando foi para a delegacia, e por sua mãe ao visitar o filho em um centro de internação, foi incorporada como sentimentos de dor e de culpa por Zezinho.

A mãe navega na ambivalência da situação do filho: ora defende aquela moral de valorização do trabalho e da família, mostrando-se então no limite do abandono de seu filho "bandido" (neste caso, destacado como adotivo), ora esta mulher é capaz de expressar sensivelmente o reconhecimento da diversidade de Zezinho, incluindo amigos ou colegas dele que flertam com o "mundo do crime". A família sofre uma investida que causa mais dor do que contribui para o fortalecimento dos laços afetivos entre os parentes, um dos

10 Segundo Gabriel Feltran “o 'mundo do crime’ é uma representação construída de modos distintos, tanto no senso comum brasileiro quanto entre adolescentes e jovens das periferias de São Paulo. Trata-se tanto de um ambiente criminal quanto de espaços de sociabilidade e produção simbólica, que têm-se expandido para além das relações entre praticantes de atos ilícitos" (2008: 13). 
objetivos propalados pelo sistema socioeducativo. No processo de execução das medidas socioeducativas, a família é chamada para tratar da cidadania que falhou, por meio de encontros com psicólogos, assistentes sociais e representantes da Justiça. Exposta a tais procedimentos, parece-me que Dona Ivone, mãe de Zezinho, sentiu-se impelida a reforçar o discurso institucional, embora sem desconsiderar circunstâncias muito particulares da vida de seu filho e dos amigos, cujo crescimento ela acompanhou.

A conduta da mãe foi influenciada por práticas pontuais de profissionais do sistema socioeducativo que revelam uma racionalidade governamental que espalha o controle de forma capilar até dentro da casa do adolescente. A ação socioeducativa, aplicada desta forma, interfere e influencia o papel de cada um dentro da família, levando à opressão dos adolescentes em seu próprio lar. No retrato que observei do conflito entre as gerações em meio a uma intervenção institucional, "fica evidente a existência de formas narrativas, simbólicas e sociais, nas quais se tece uma violência difusa [...] no processo de sua articulação, às vezes de sua prática, a violência parece definir os contornos dentro dos quais ocorre a experiência de uma forma de vida enquanto forma de vida humana" (Das 1999: 36). O sistema socioeducativo, através de suas práticas de intervenção, causou desacordos e desassossegos para Zezinho e para seus parentes.

A representação dramática de que Zezinho participou indica que a marca da privação de liberdade constitui, para os adolescentes, um estigma de segregação dificilmente superável. A dramatização revela a leitura que eles fazem de suas próprias experiências entre as fronteiras do consumo e do tráfico de drogas, da pobreza, do preconceito e da falta de oportunidades. De forma crescente, os adolescentes são presos por crime de tráfico; na singeleza do teatro, os jovens internados na Fundação Casa exibiram o sentimento do risco constante que sofrem: eles podem perder a liberdade por consumirem ou por venderem drogas em pequenas quantidades.

Ao passar da medida socioeducativa de internação para a de liberdade assistida, Zezinho, inicialmente, compreendeu essa última como um ritual burocrático que deveria ser cumprido para atender à determinação do juiz. Identificou na medida um controle total, um big brother em que o juiz representa o poder central, a psicóloga a "mensageira", e a polícia mais a escola os "tentáculos" que, em seu próprio território, o observam e o constrangem. Expressar cólera e revolta no contexto do atendimento socioeducativo é correr o risco de ser enquadrado em alguma psicopatologia. Vistas como entidades reais e universais, as emoções são subsumidas na biomedicina e na psicologia em esquemas normativos (saúde/doença, normal/patológico) como lócus sujeito a controle, regulação e tratamento (Epele 2010: 224). Zezinho sabe que suas reações emocionais estão sendo permanentemente monitoradas pela psicóloga, para que ela possa saber da sua "verdade interna" e intervir para protegê-lo de seu potencial de reincidência. 
A aflição que o adolescente sentia ao ser tido como um suspeito (na escola, nas ruas, nos espaços públicos) era por ele contida quando submetido aos encontros com a psicóloga. Ele buscou demonstrar controle emocional, embora tenha passado por uma série de acontecimentos que considerou opressores: após a "batida" policial e o consequente constrangimento pelo qual passou na lanchonete, justamente no dia do aniversário de sua cidade, Zezinho não construiu naquele momento uma narrativa sobre sua revolta, sua dor - ele apenas afirmou, com raiva: "Eu vou traficar mesmo!" Algumas semanas após o acontecimento, eu voltei ao assunto com ele e, então, ele interpretou o acontecimento de forma ampliada, organizando uma exposição de aspectos mais perenes em sua vida: citou sua mãe, a dedicação da vida inteira ao trabalho de empregada doméstica e a pobreza persistente, e da avaliação da situação da mãe conjecturou sobre sua própria vida: "Eu nasci aqui na favela; eles nunca vão me dar um boi". ${ }^{11}$ Perguntei-lhe: "Eles quem?" "A sociedade", respondeu. Zezinho realiza uma interpretação por meio do sistema de valores do qual decorre a afetividade manifesta. Ele passou por uma cena pública de depreciação, sentiu-se desvalorizado e diminuído. Mas também elaborou sua relação com o mundo a partir de uma perspectiva de confronto com o que chamou de "sociedade". A raiva surgiu como expressão emotiva de sua relação com o mundo.

O contexto de vida de um adolescente como Zezinho é permeado por violências institucionalizadas no estado de São Paulo. Os adolescentes em cumprimento de medidas socioeducativas costumam viver em territórios urbanos de baixa renda genericamente chamados de "periferias". O aprisionamento dos jovens moradores de zonas urbanas de baixa renda constitui atualmente política estatal: tal política é praticada por meio da "guerra às drogas" em bairros considerados de "alta vulnerabilidade", o que sugere a prática governamental de punir a pobreza e de conter as inúmeras "patologias" a ela associadas (Wacquant 2008). Parte substantiva dos jovens que estão no sistema socioeducativo advém destas zonas urbanas.

A periferia expressa, simbolicamente, um lócus existencial onde pessoas insuficientemente socializadas, segundo o marco normativo, podem sofrer interferências em suas vidas. Os jovens pobres, no discurso da "fala do crime", constituem o principal grupo em risco de sucumbir ao crime, ao mal: ${ }^{12}$

"são considerados muito jovens para se protegerem do mal por si mesmos, e por não serem totalmente racionais, ainda, precisam ser controlados.

11 A expressão "dar um boi" significa dar uma chance, uma oportunidade.

12 Caldeira (2000: 27) define a "fala do crime" como "todos os tipos de conversas, comentários, narrativas, piadas, debates e brincadeiras que têm o crime e o medo como tema”. Este discurso é corrente na sociedade brasileira das últimas décadas. 
Por serem homens, resistem ao controle e são atraídos pelos ambientes em que o mal abunda, principalmente a rua. Ali encontram as drogas, que perturbam sua consciência e os transformam em alvos fáceis para as forças do mal" (Caldeira 2000: 90).

Como consequência lógica deste discurso, os limites entre delinquência e insensatez ficam extremamente tênues e legitimam o controle sobre segmentos jovens de baixa renda.

A centralidade no sistema socioeducativo de jovens "da periferia" expressa a dinâmica da disputa simbólica que se dá, por meio do processo de expansão do marco discursivo do "crime", entre jovens que habitam as periferias paulistas (Feltran 2008). Atualmente, entre os jovens,

“... essa disputa contribui para a ressignificação do trabalho como ganho, dos projetos de vida em longo prazo como premência por curtir o presente e de uma religiosidade centrada na vida eterna por outra, mais conectada às experiências-limite vividas no mundo" (Feltran 2008: 194).

Por outro lado, "de fora para dentro", esta figuração se confunde com a criminalização das periferias. A repressão policial se volta a todos que se "parecem" com "bandidos", isto é: "que têm a mesma idade e cor de pele, que usam roupas semelhantes ou os mesmos acessórios que aqueles identificados publicamente como criminosos, ou seja, os jovens das periferias urbanas" (Feltran 2008: 195).

Uma série de características atribuídas ao "ladrão", como as de adotar o risco como estilo de vida, a busca do dinheiro fácil, do poder e do prestígio locais, são elementos de performances corporais e de narrativas dos jovens. Estas explicitam experiências adquiridas a partir de relações interpessoais ou institucionalizadas, de informações acumuladas numa ampla representação de falas e imagens veiculadas pelos meios de comunicação e constantemente ressignificadas na música e no cinema. Ser membro do "mundo do crime" é participar de formas de identificação coletiva valorizadas por muitos jovens. Além disto, trabalhar no tráfico é estar em uma posição de destaque na economia local. "Frieza" e "cálculo" são qualidades necessárias que combinam com uma inteligência prática, senso de oportunidade e a arte de contornar situações difíceis, comum à "viração" das classes populares brasileiras (Teles e Hirata 2007). $\mathrm{Na}$ rua, Zezinho percebe que está ali, na frente da sua casa, a possibilidade de conseguir, em tempos de crise, $\mathrm{R} \$ 700,00$ em uma semana. ${ }^{13}$ A escolha por traficar é também uma escolha econômica. 
Zezinho passou por uma intervenção imposta a ele como algo feito para protegê-lo dele próprio e de seu contexto de "vulnerabilidades". Complementando a ação de repressão (a "guerra às drogas"), o modelo de intervenção socioeducativo é posto como um tratamento legítimo para o sofrimento e violações de direitos que o adolescente sofreu por ser de um "território de vulnerabilidades" e trabalhar no tráfico. Ao se encarregar dos adolescentes, tidos ora como vítimas ora como membros do tráfico de drogas, o sistema socioeducativo instaura o controle e os cuidados, através de dispositivos jurídicos, psicológicos e assistenciais para o tratamento desta "população vulnerável”. A psicóloga que fazia o acompanhamento de Zezinho me disse certa vez que o seu trabalho é tornar o adolescente consciente de suas escolhas e das consequências delas: "Se ele quer trabalhar no tráfico de drogas, tem que estar consciente que ele provavelmente será preso e, talvez, até morto".

O processo de individualização da responsabilidade se coaduna bem com a noção corrente de empreendedorismo que se amplia para remotas fronteiras da vida social; o empreendedorismo é hoje uma palavra-chave nas estratégias pedagógicas, socioeducativas. O sistema socioeducativo tem hoje um objetivo principal: evitar a reincidência. A "socioeducação" deve ser capaz de suprimir um nível do comportamento do indivíduo. No caso dos adolescentes que trabalham no tráfico de drogas, o sentido da ação socioeducativa é mudar o comportamento em seu elemento econômico, a atividade de vender drogas. Os critérios psicológicos para a caracterização do adolescente continuam recorrentes e atuantes: análise da memória pessoal, da trajetória de vida com o ambiente familiar, da capacidade de ver a realidade, da permanência ou não dos traços de personalidade e caráter. Essas práticas avaliam se o indivíduo tem o juízo das "corretas" intenções, crenças e valores, assim como o raciocínio normal. Acontece que o conteúdo da normalidade psicológica esperada implica necessariamente abandonar a venda de substâncias psicoativas ilegais, como se este trabalho fosse em si um sintoma, um distúrbio de ordem psicológica.

O trabalho no tráfico de drogas se revela como experiência cotidiana em que ocorre um conjunto de situações de opressão e violência. Ao dispor a linguagem e a gestualidade no "estilo bandido", Zezinho interiorizou uma posição em um campo de relações de poder e passou pelo fio da navalha, entre o crime e o socioeducativo, inaceitável para toda sua rede de relações. Para os operadores do sistema socioeducativo ele procurou se mostrar firme, disposto a "pegar na pá e na enxada”, caso necessário, a empreender uma transformação de seu contexto de vida. Para o sistema do crime, "ladrão não fica entre a cruz e a espada", ele tinha que se mostrar adequado à firma, ${ }^{14}$ vestir a camisa e arcar com as consequências. Zezinho não pode ter dúvidas, ele deve empreender 
a si mesmo, correndo os riscos inerentes à vida loka do trabalho no comércio varejista de drogas. Tal visão do jovem como alguém que deve explorar individualmente os riscos, as perdas e as benesses de suas escolhas constitui uma zona de confluência entre o discurso socioeducativo e o do crime. Zezinho circulou durante os meses que eu o acompanhei por múltiplos níveis em que ideias, projetos e técnicas o influenciaram para um alinhamento com uma noção geral de competência pessoal, de capacidade de governar a si mesmo. Vivendo como suspeito em seu próprio bairro, Zezinho tem que escolher os meios, os caminhos e os instrumentos para o sucesso de sua empreitada individual. Simultaneamente um aparato governamental difuso e um modelo de gestão do comércio de drogas o acompanharam, cada qual dos sistemas com suas próprias estratégias e esquemas de gestão da vida do adolescente.

$\mathrm{O}$ ato infracional é definido no ECA como "a conduta descrita como crime ou contravenção penal" (art. $\left.{ }^{\circ} 103 .^{\circ}\right)$, conteúdo operativo, mecânico e vazio de sentido. Partindo da definição padrão de crime (uma infração à lei formulada) elaborada pelos reformadores do direito penal no final do século XVIII, Foucault observa que na análise dos neoliberais a definição é a mesma, mas o ponto de vista simplesmente muda: o crime é colocado do lado de quem comete o ato, passa-se para o sujeito individual e, assim, a infração à lei é definida como a ação que o indivíduo realiza que faz com que ele corra o risco de ser punido. ${ }^{15}$ O empreendedorismo de si mesmo pode ser visto como uma faceta da difusão de uma grade de inteligibilidade neoliberal, isto é, a eleição do mercado como princípio de inteligibilidade tanto dos comportamentos individuais quanto das ações governamentais (Foucault 2008a). ${ }^{16}$

No caso de Zezinho, na forma como sua psicóloga elaborou sua intervenção, a questão é mostrar ao adolescente que a ação de traficar o faz correr o risco de receber uma medida socioeducativa (ou de ser morto, o que também seria consequência de sua escolha individual). Embora, no Brasil, tanto a internação quanto o homicídio de adolescentes sejam formas de violência estrutural, o discurso corrente volta à responsabilidade para o próprio autor do ato infracional. Zezinho entra nos cálculos do poder e, a partir de seu

15 Segundo Foucault $(1996,2008$ a), a questão colocada pelos reformadores era uma questão de economia política: "Filtrando assim toda a prática penal através de um cálculo de utilidade, o que os reformadores buscavam era precisamente um sistema penal cujo custo fosse o mais baixo possível" [...] "a lei é a solução mais econômica para punir devidamente as pessoas e para que essa punição seja eficaz" (Foucault 2008a: 340-341).

16 Ao tratar das análises neoliberais em seu contexto geral, Foucault revela que a economia passa a ter como tarefa, não criar um mecanismo relacional entre capital, investimento e produção, mas analisar o comportamento humano e sua racionalidade interna: "O que a análise deve tentar esclarecer é qual cálculo que aliás pode ser despropositado, pode ser cego, que pode ser insuficiente, mas qual cálculo fez que, dado certos recursos raros, um indivíduo ou indivíduos tenham decidido atribuí-los a este fim e não àquele. A economia não é, portanto, a análise lógica histórica de processo, é a análise da racionalidade interna, da programação estratégica da atividade dos indivíduos" (2008a: 307). 
comportamento econômico (vendedor de substâncias psicoativas ilegais), passa a ser governamentalizável (Foucault 2008a: 345). ${ }^{17}$

O sistema socioeducativo é uma inovação do Estado brasileiro. Sua ambiguidade complexifica as relações de poder que transpassam a experiência de um jovem como o Zezinho. Ao situar os adolescentes como sujeitos de direitos, o discurso institucional representa a possibilidade de os adolescentes mudarem o comportamento desviante e assim se incorporarem à sociedade. Desta forma, as instituições do sistema socioeducativo fazem a sua parte, cumprem suas funções racionais de controle da criminalidade e, ao mesmo tempo, promovem oportunidades de construção de cidadania. O Estado constrói, assim, desde a margem, a marca de distinção entre jovens aptos a voltarem ao convívio social e jovens reincidentes. O sistema socioeducativo garante ao jovem o direito de se "ressocializar"; permite que ele, por meio de sua razão individual, transponha a fronteira do "mundo do crime". Se o jovem não a transpuser, isto indica fraqueza individual (e da família), incapacidade de empreender um comportamento econômico que não seja um crime.

17 O índice de homicídios de adolescentes divulgado em julho de 2009 aponta o fato de que metade das mortes de jovens brasileiros entre 12 e 18 anos é causada por homicídio. Além disto, a mesma pesquisa estima, baseada nos números de 2006, que entre o ano citado e 2012, aproximadamente 33 mil adolescentes morrerão como vítimas de homicídio (UNICEF 2009). Simultaneamente, há, também, o incremento expressivo de adolescentes em privação de liberdade. Em 2007, a Secretaria Especial dos Direitos Humanos (SEDH) da Presidência da República divulgou dados do "Levantamento Nacional do Atendimento a Adolescentes em Conflito com a Lei”, mostrando o aumento em 363\% do número de jovens internados entre 1997 e 2007, chegando hoje a dezenas de milhares em todo o país (Documento Referencial para o Sistema Nacional de Atendimento Socioeducativo: SINASE, 2005, Brasília, Secretaria Especial dos Direitos Humanos). 


\section{BIBLIOGRAFIA}

BIONDI, Karina, 2010, Junto e Misturado: Uma Etnografia do PCC. São Paulo, Editora Terceiro Nome.

CAldeira, Tereza P.R., 2000, Cidade de Muros: Crime, Segregação e Cidadania em São Paulo. São Paulo, Edusp.

DAS, Veena, 1999, "Fronteiras, violência e o trabalho do tempo: alguns temas wittgensteinianos", Revista Brasileira de Ciência Sociais, 14 (40): 31-42.

—, 2006, Life and Words: Violence and Descent into the Ordinary. Berkeley, University of California Press.

DAS, Veena, e Deborah POOLE, 2008, “El estado y sus márgenes: etnografias comparadas", Cuadernos de Antropología Social, 27: 19-52.

EPELE, Maria, 2010, Sujetar por la Herida: Uma Etnografia sobre Drogas, Pobreza y Salud. Buenos Aires, Paidós.

FELTRAN, Gabriel S., 2008, Fronteiras em Tensão: Um Estudo sobre Política e Violência nas Periferias de São Paulo. São Paulo, Unicamp, tese de doutoramento em Ciências Sociais.

FONSECA, Cláudia, 2005, "Concepção de família e prática de intervenção”, Saúde e Sociedade, 14 (2): 50-59.

FOUCAUlT, Michel, 1996, Vigiar e Punir: História da Violência nas Prisões. Petrópolis, Vozes.

—., 2001, História da Sexualidade: A Vontade de Saber. Rio de Janeiro, Graal.

—_, 2008a, Nascimento da Biopolítica: Curso Dado no Collège de France (1978-1979). São Paulo, Martins Fontes.

—_, 2008b, Segurança, Território e População: Curso Dado no Collège de France (1977-1978). São Paulo, Martins Fontes.

GEERTZ, Clifford, 2001, Nova Luz sobre a Antropologia. Rio de Janeiro, Zahar.

KLEINMAN, Arthur, Veena DAS, e Margareth LOCK (orgs.), 1997, Social Suffering. Berkeley, University of California Press.

MALVASI, Paulo Artur, 2011 , "Entre a frieza, o cálculo e a 'vida loka': violência e sofrimento no trajeto de um adolescente em cumprimento de medida socioeducativa”, Saúde e Sociedade, 20 (1): 156-170.

TELES, Vera da Silva, e Daniel Veloso HIRATA, 2007, "Cidade e práticas urbanas: nas fronteiras incertas entre o ilegal, o informal e o ilícito”, Revista Estudos Avançados (Dossiê Crime Organizado), 21 (61): 173-191.

UNICEF, 2009, Índice de Homicídios na Adolescência (IHA). Brasília, UNICEF.

WACQUANT, Loïc, 2008, "A penalização da miséria e o avanço do neoliberalismo", em Loïc Wacquant, As Duas Faces do Gueto. São Paulo, Boitempo, 93-105.

Self-entrepreneur under suspicion: path and suffering of a teenager during socio-educational intervention - Paulo Artur Malvasi - Universidade Bandeirante de São Paulo, Brasil • paulomalvasi@hotmail.com.

This study examines the social and political nature of the suffering of a young person subjected to "socio-educational measure". From a Foucaultian perspective of power, the article considers the subjective experience of the young individual in his interaction with the socio-educational system, and observes how power is manifested in the acts of some over others, in the reiterated deeds revolving around 
knowledge and authority that delineate the ways of action of the youngster within his own field of action. The analysis of the subjective experience of the teenager subjected to a socio-educational measure shows how that intervention can place him at the limits of the possibility for integration, intensifying the sufferings of a life under constant suspicion. The adopted approach allows us to observe how this young person produces meanings about the socio-educational system and how he expresses through words, gestures and movements the contradictions of the public policy. The position of the teenager as someone who should individually explore the risks, the losses and the gains of his own choices defines an area of confluence between the socio-educational speech and that of crime. Simultaneously, a diffuse government apparatus and a management model of the drugs trade compete in the path of the youngster subjected to socio-educational measure, each of the systems having its own strategies and management schemes for his life.

KEYWORDS: social suffering, power and violence, socio-educational measure. 